\title{
Influence and Challenges of the Capitation Grant on Education Delivery in Basic Schools in Ghana
}

\begin{tabular}{l}
\hline Edison Pajibo' (D) \\
Emmanuel M. J. Tamanja ${ }^{2}$ (D) \\
University of Education, Winneba, Ghana \\
Resesponding Author)
\end{tabular}

\begin{abstract}
In Ghana, some children do not attend school, because their parents are unable to afford levies and fees charged by schools. This led to the introduction of the Capitation Grant Scheme in 2005. This study investigates the influence of the Capitation Grant Scheme on education delivery in basic schools in Ghana, through a close study of the Ga West Municipality. It is a descriptive survey, involving teachers, head teachers and parents as the target population. Purposive, stratified and simple random sampling techniques were used to select participants, while questionnaire and documentary sources were used as instruments to gather information which was summarized statistically in percentages and analysed in themes. The main finding revealed that the introduction of the Capitation Grant Scheme was found to be very relevant and has led to an increase in enrolment in basic schools. However, the increase in enrolment brought about some challenges such as inadequate classrooms, furniture, textbooks, teaching and learning materials and a high pupil-teacher ratio. The researchers recommend an increase in the quantum of the grant per pupil and direct payment into the accounts of schools to reduce annual delays in disbursement.
\end{abstract}

\section{Keywords: Capitation grant, Education delivery, Basic school, Policy, Scheme.}

\section{Contents}

1. Background and Context

2. Literature

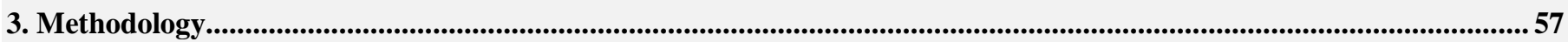

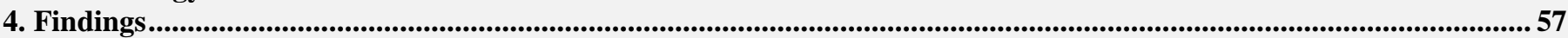

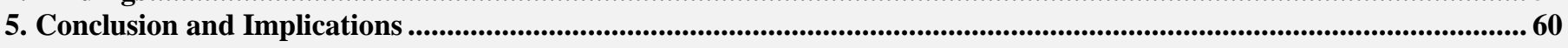

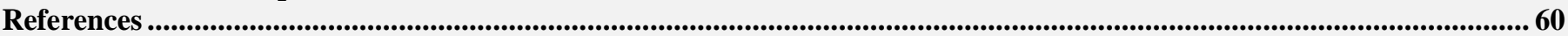

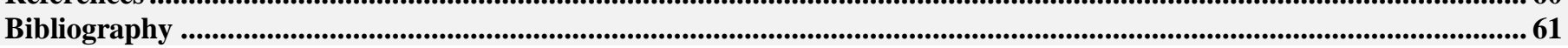

Citation | Edison Pajibo; Emmanuel M. J. Tamanja (2017). Influence and Challenges of the Capitation Grant on Education Delivery in Basic Schools in Ghana. Asian Journal of Education and Training, 3(1): 53-63.
DOI: 10.20448 /journal.522.2017.31.53.63 2519-5387
ISSN(E) :
This work is licensed under a Creative Commons Attribution 3.0 License (co))
Licensed:
All authors contributed to the conception and design of the study.
Funding: This study received no specific financial support.
Competing Interests The authors declare that they have no conflict of interests.
Transparency:
The authors confirm that the manuscript is an honest, accurate, and transparent account of the study was reported; that no
History:
Ethical: vital features of the study have been omitted; and that any discrepancies from the study as planned have been explained. Received: 20 February 2017/ Revised: 24 March 2017/ Accepted: 30 March 2017/ Published: 5 April 2017
Publisher: This study follows all ethical practices during writing. Asian Online Journal Publishing Group 


\section{Background and Context}

Education is a human right that has immense power to transform society. Its foundation rests on the cornerstones of freedom, democracy and sustainable human development. It can provide children with the knowledge and skills they need to succeed in life and is associated with increased incomes, reduced poverty and improved health (UNICEF, 2006). Naturally, the thinking is that when the right to education is assured, the whole world gains. There are no instant solutions to violations of that right, but it begins with a simple proposition: that on the eve of the $21^{\text {st }}$ Century, there is no higher priority, and no mission that is more important than that of Education For All.

Recalling the words of Governor Guggisberg, 'Education is the cornerstone of a people's life and happiness' (Mcwilliam and Kwamena-Poh, 1975). Drucker (2006) noted that an abundant and increasing supply of highly educated people has become an absolute prerequisite for social and economic development in the world. It would seem logical that politicians and educators have come to accept this fact. Denison (2007) noted that about 21 percent of the economic growth in the United States, between 1929 and 1957 was attributed to education. According to him, this contribution of schooling exceeded that of material capital. Sadly, however, "about 124 million children and adolescents are denied opportunities to enter and complete school - including around 59 million children of primary school age and 65 million young adolescents of lower secondary school age while more than half of the primary school - aged children who are not in school live in sub-Saharan Africa" (UNICEF, 2016).

Nevertheless, most African countries have started devoting substantial proportion of their incomes as well as their foreign aid to the education sector. This awareness is also seen in the Declaration of the Conference of African States held in Addis Ababa in 1961 that 'Education is Africa's most urgent and vital need, and that education is a matter of key developmental importance throughout the world (Dzamboe, 2005). Cognisant of the importance of education to national development, various governments have contributed to the advancement of the educational system in Ghana. The ideological underpinning is the continuing aim to make education more relevant to the world of work after school, to rural development and modernization of the predominantly agriculture-based economy, as well as to promote national and cultural identity, and citizenship. Based on these propositions, several education reforms have been instituted at one time or the other since 1951, ostensibly to make education more accessible to every section of the society. Some of these educational reforms, according to Adedze (2005) include:

a. For numbered lists Accelerated Development Plan of Education of 1951

b. The Education Act of 1961

c. The Education Review Committee 1967

d. The Dzobo Education Reform Programme of 1974

e. The Educational Reform Program of 1987

$\mathrm{f}$. The Review of Education Reforms in Ghana in 2002

These educational reviews and reforms were intended to strengthen the educational system. However, over the years, the cumulative effects of these educational reviews and reforms have not met the desired objectives of achieving access and appropriate educational management at the basic level. Antwi (1992) opines that educational reforms must be borne out of evolving social needs. Hence, in 2005, the Government of Ghana introduced the Capitation Grant policy aimed at meeting the educational needs of access and school management. Capitation is a payment of an equal amount of money to each person (in the context of this research, for each basic school pupil).

The introduction of the Capitation Grant is rooted in the 1992 Constitution of the Republic of Ghana, which made provision for a policy on free education to be implemented within two years of its coming into force. This led to the policy of Free Compulsory Universal Basic Education (FCUBE). The FCUBE Policy requires that every Ghanaian received basic education by 2005, at the expense of the State. Specifically, Article 25 of the 1992 Constitution states that 'all persons shall have the right to equal educational opportunities and facilities and with a view of achieving the full realization of that right, basic education shall be free and compulsory to all'. However, the implementation of the FCUBE could not be achieved in full, with regards to its primary aim of accessibility and free education, due to unfavorable economic conditions of the country (Atagra, 2005).

To enable all school-going age children in Ghana attend school, the government introduced the Capitation Grant Scheme in 2005. Prior to the introduction of the capitation grant, basic school enrolment rate decreased by 5\% (Akyeampong et al., 2007). As shown in Figure 1, enrolment decreased from 3.7 to 3.6 million pupils between 2004 and 2005 .

The scheme, which started with some pilot districts, now has been extended to embrace all public basic schools in the country with effect from September, 2005. Under the scheme, GH $₫ 4.5$ (equivalent to US $\$ 1.40$ as of January, 2015 ) per child per annum is paid to all basic school pupils in all public schools in the country (Bonney, 2006). But it can be well argued that many educational policies and or programmes have always raised critical controversies and therefore, require research and serious lengthy public debates to arrive at what is appropriate and acceptable to the society in general to become good social policies. The capitation grant was to give schools the necessary funds to improve teaching and learning, manage and relief financial burdens of parents (Ministry of Education Science and Sports, 2005) as several levies (see Figure 2) were imposed as a way of schools making up for inadequate funding.

The introduction of the Capitation Grant, though lauded by many Ghanaians, is criticized by others. However, soon after the introduction of the grant, net enrolment increased by $6 \%$ in just one year and then increased to over $10 \%$ (see figure 3) in three years (Akyeampong et al., 2007).

Despite various interventions to salvage the teething problems of the Grant through workshops and other sensitization programmes, the full influence and challenges of the Grant are yet to be ascertained in terms of enrolment of pupils in public basic schools in Ghana (Dzamboe, 2005).

\subsection{Research Problem}

The prevailing argument is that, in spite of the efforts and provisions made by various governments in ensuring accessible and free compulsory basic education in the country, including the introduction of the Capitation Grant, 
there are still some Ghanaians who are either semi-literate or illiterate and children of school-going age who are not in school (Dzamboe, 2005). As in other parts of Ghana, provision of formal education has been part of the challenges of the Ga West Municipality for a very long time. There are 106 public basic schools in the Municipality. These schools are beneficiaries of the Capitation Grant introduced nationwide by the government in the 2004 12005 academic year. This notwithstanding, the community lags behind in education despite the introduction of the Capitation Grant.

This study therefore, seeks to answer the key question of how the Capitation Grant Scheme influenced education delivery and the attendant challenges in public basic schools in the Ga West Municipality in Ghana.

\subsection{Research Questions}

The need for a systematic unveiling of the influence of the capitation grant resulted in the formation of the following research questions:

- What influence does the Capitation Grant scheme have on public basic schools in the Ga West Municipality in Ghana?

- What factors serve as impediments to the full implementation of the grant in public basic schools in Ga West Municipality?

- In what way(s) can stakeholders improve education delivery in Ga West Municipality using the Capitation Grant?

\subsection{Purpose and Significance}

This study sought to investigate the influence of the Capitation Grant scheme on education delivery in public basic schools through a close study of the Ga West Municipality of the Greater Accra Region in Ghana. The study will be of great importance to educational stakeholders such as the GES and the Ministry of Education by creating awareness on the challenges bedeviling the Capitation Grant scheme. It will also help educational stakeholders to effectively implement the scheme by appreciating the problems that have arisen as a result of its introduction.

\section{Literature}

Available literature suggests that capitation grant, like any social intervention, would have some influence (both negative and positive) on education (Denison, 2007).

\subsection{Gains of the Capitation Grant \\ 2.1.1. High Enrolment}

Some authorities have argued that the introduction of the policy in Ghana has contributed in getting more children in schools. A report from the United Nations Educational, Scientific and Cultural Organization (UNESCO) revealed that Universal Primary Education has been well received, according to various stakeholders such as the Ghana Education Service (GES), the Ministry of Education (MOE) and Parents (UNESCO, 2006). Among the SubSaharan African countries to adopt this policy was Uganda in 1997 and with the introduction of this policy, the country experienced a robust increase of primary enrolment from 2.8 million in 1997, to 10.7 million in 2013 (Agyeman, 2013). This has not been different in Ghana. For example, Atagra (2005) argues that the implementation of the Capitation Grant Scheme in September, 2005 increased enrolment in pre- schools by $24.5 \%$ and primary school by $9.3 \%$. Specifically, enrolment increased to 3,698,448 in $2004 \backslash 2005$ academic year, representing $16.7 \%$ increase in a year compared to gross enrolment ratios over the past few years, which stood at an average of $1.7 \%$. At present, the Capitation grant has led to enrolment of more than 10.7 million children in school (Agyeman, 2013). Although the data is impressive at the national level, the extent to which the grant has specifically influenced enrolment in the Ga West Municipality is not ascertained.

The Gross Enrolment Ratio (GER) in primary schools increased by $18.6 \%$ points from 86.4 percent in 2005/2006, the year immediately after the nationwide roll-out of the capitation grant, to 105\% in 2012/2013 (Figure $4)$.

This is significantly higher than the rate of increase before the capitation grant scheme was introduced, which was only about 3.3 percentage points from $80 \%$ in $2001 / 02$ to $83.3 \%$ in 2004/05. The GER in JHS also increased at a rate of $11.8 \%$ from $70.4 \%$ in $2005 / 2006$, the year immediately after the nationwide rollout of the capitation grant, to $82.2 \%$ in 2012/2013. This is significantly higher than the rate of increase before the introduction of the capitation grant scheme which was only $6.2 \%$ from $64 \%$ in $2001 / 02$ to $70.2 \%$ in $2004 / 05$. Primary schools experienced the most significant NER increase from 2005/06 (immediately after the introduction of the capitation grant), increasing at a rate of 15.3 percentage points from $68.8 \%$ in 2005//06 to 84\% in 2012/13 (Figure 5).

This is significantly higher than the rate of increase between 2001/02 and 2004/05 which was only $0.1 \%$. The NER in JHS increased at a rate of 6 percentage points between 2005/06 and 2012/13 from $41.6 \%$ to $47.8 \%$. This is significantly higher than the rate of increase before the capitation grant scheme which was about 3.3 percentage points from $80 \%$ in $2001 / 02$ to $83.3 \%$ in $2004 / 05$. The NER in pre-schools remained almost the same before and after the capitation grant scheme at $23.5 \%$ and $24.8 \%$, respectively. This notwithstanding, the Ga Municipality lags behind in education despite the introduction of the Capitation Grant.

\subsubsection{Gender Disparities in Enrolment Levels}

The Gross Enrolment Ratio (GER) and Net Enrolment Ratio (NER) in primary schools of boys continue to be slightly above that of girls over the years from 2001 until 2012, even though the gap in NER seems narrower compared to the GER (Figure 6).

The GER seemed to have matched in the 2012/13 academic year signifying an overall improvement in girls' GER at the primary school level. The gap between boys and girls in terms of NER has on average been closing up. 
The gap was wider in 2001 and 2002, around three percentage points, but closed up towards 2005. As reflected in the GER, since 2009 the gap between boys and girls in NER in primary schools has closed up quite considerably to a difference of only 0.3 percentage points. There is however, a wider gap in GER at the JHS level between boys and girls, continuously moving towards boys, and averaging around seven percentage points. One could argue that the gap between girls and boys closed due to the government's policy on girl-child education.

The NER on the other hand increased remarkably immediately after the introduction of the capitation grant for both boys and girls in JHS before declining in 2008 (Figure 7).

It averaged around 54\% and $51.8 \%$ for boys and girls respectively, at a rate of 10 percentage points between 2005 and 2007. Since 2008, the NER for JHS has been declining, and declining much faster for girls compared to boys. It only started to peak again around 2010 .

Unlike for Primary schools, the gap between boys and girls NER at JHS has been widening. While before the introduction of the capitation grant (2001-2004), NER for girls in JHS was slightly above boys; the trend reversed since 2006 and the gap has since been widening. The disparity increased significantly between 2008 and 2009 at a rate of 4.7 percentage points. Even though this declined to less than two percent in 2011, the gap widened again to nearly seven percentage points in 2012. The implication of this is that not all girls completing primary school enter into JHS. This requires serious policy attention, especially with regard to some socio-cultural and economic practices that give preference to boys in making educational choices for children in the family.

It can fairly be argued as per the data in Figures 6 and 7 that enrolment rates for boys and girls in basic school increased up to 2013 but decreased in 2014. A plausible explanation of this could be that, there were challenges with the disbursement of statutory funds for the Grant. Some of these challenges are expatiated in the next section of the review.

\subsection{Challenges of the Capitation Grant}

\subsubsection{Shift System and Inadequate Infrastructure}

The experience of high enrolment, generates a problem by which classrooms can hardly accommodate the large number of intake of pupils. Dzamboe (2005) opines that as a result of introduction of the Grant some authorities adopted the shift system where some students attend school in the morning while others come in the afternoon. One clear impression that does emerge in terms of this challenge relates to the failure of educational planners to build more infrastructure to accommodate the anticipated large influx of school children.

\subsubsection{Inadequate Infrastructure}

Additionally, the introduction of the Capitation Grant Scheme has brought enormous challenges to the government, as a result of the increase in enrolment. Gross enrolment for primary education reached $107.4 \%$ in the 2015/2016 academic year. One of such challenge is the provision of more infrastructures for basic schools. For instance, Bonney (2006) reported in the Saturday, January 14, Edition of the Daily Graphic, that the Secretary of the Conference of Heads of Basic Schools (C.H.O.B.S.) urged the government as a matter of urgency, to provide more classrooms and furniture to cater for the increase in enrolment. Lack of attention in addressing this problem constitutes another policy challenge in terms of educational planning. Essentially, when classes become too large or overcrowded and resources are not increased proportionately, the results can reverse the hard-earned gains and demotivate teachers, parents and pupils.

\subsubsection{Changes in Pupil-Teacher Ratio}

The Pupil-teacher ratio (PTR) in basic schools as reported in Education Management Information Service (EMIS) shows a slight increase from an average of 27 pupils to a teacher in the period before the capitation grant (2001-2004) to about 28 pupils to a teacher in the period after the introduction of the capitation grant (2005-2013). A plausible explanation for the upward change in the pupil-teacher ratio could be the disproportionate enrolment of pupils to the number of teachers the government employed within the period of 2001 to 2005.

As shown in Figure 8, during the 2009/10 academic year, the pupil-teacher ratio declined remarkably to about $21: 1$, but rose to 28 pupils to a teacher in 2012/13. However, Ghana's PTR is still significantly below the ratio in neighbouring countries which is slightly above the ideal ratio of 40:1 or less. According to the Education Strategic Plan (ESP), Government set a long-term target of PTR at kindergarten level at 25 and primary schools at 35 (World Bank, 2011). Clearly, the ratios do not indicate a worse PTR in basic schools in Ghana by the GES standards of 35:1.

\subsubsection{Provision of Teaching and Learning Materials}

High enrolment of students has also resulted in inadequate provision of teaching and learning materials. The Ghana National Education Campaign Coalition (G.N.E.C.C.) held a press conference on Ghana's Educational Policy Direction at the Accra International Press Centre on the $8^{\text {th }}$ August, 2012. It held the view that the improvement upon the quality of pupils in basic schools also depends on pupil- textbook ratio (Atagra, 2005). Unfortunately, the supply of textbooks is inadequate, coupled with high enrolment as a result of the introduction of the capitation grant.

\subsubsection{Inadequacy of the Grant}

An analysis of the background issues and the views expressed in the literature show that the Capitation Grant Scheme reflects two major strategic directives. The first is the Fee Free Tuition and the second is the School Capitation to replace levies. Currently, the government pays GH $\not 4.5$ (this was equivalent to approx. US $\$ 1.40$ as of January, 2015) per annum per pupil enrolled. However, some of the amount is used for sports and cultural activities and the remaining for the provision of teaching and learning materials, minor repairs in the schools, and examination (Dzamboe, 2005). 


\subsection{Study Area}

The Ga West Municipality was created in 2008 and forms part of 16 metropolis, municipalities and districts in the Greater Accra Region. The Municipality was carved out of the erstwhile Ga District which was created in 1988. In 2004, the Ga District was divided into two Districts namely, Ga East and Ga West and in 2008, Ga West District was further divided into Ga West and Ga South Municipalities with Amasaman the former district capital remaining the capital for the newly created Ga West Municipality (study district). It shares boundaries with the Ga East and the Accra Metropolitan Area to the East, Akwapem South to the North, Ga South to the South and Ga Central to the North-South and occupies a total land surface area of 299.578 square kilometres (Ghana Statistical Service (GSS), 2014) with 102 basic schools and gross enrolment of 37,245 in 2014/15 academic year (Ministry of Education (MOE), 2001).

The rationale for selecting the Ga West Municipality is that, it represents one of the municipality that was previously part of an existing district and lies in the peri-urban area, hence assuming some characteristics of both rural and urban centres. This will make generalization easier.

\section{Methodology}

\subsection{Research Design}

The study adopted the descriptive survey design that focused on the influence of the Capitation Grant on basic education delivery in the Ga West Municipality. The survey design allowed the gathering of information from a large population (from schools) and from secondary sources (documents) made room for generalization. The researchers obtained numerical data that were translated into frequency tables and percentages.

\subsection{Population}

The target population of the study constituted section of the stakeholders of the Capitation Grant Scheme. These included head teachers, teachers as well as parents. Available data from the Education Management Information System (EMIS) for 2014/15 academic year indicate 203 public basic schools, consisting of 2 Nurseries, 65 Kindergartens, 69 Primary and 67 Junior High Schools in the Ga West Municipality.

\subsection{Sampling}

A sample of 15 basic schools (consisting of primary and JHS) were purposely and randomly selected for this study. The schools were first stratified into circuits, from which at least a school was selected to ensure that all the educational circuits were represented. Head teaches from the sampled schools were automatic members while 5 teachers were randomly selected in each school. This was intended to give all teachers the opportunity to be selected. Incidental sampling was used to select 3 parents each, from the communities where the 15 selected schools were located. In all, a total of 138 participants (15 head teachers, 75 teachers, 45 parents and 3 circuit supervisors) participated in the study.

A questionnaire was developed and used to obtain primary data while documents were used as secondary data. The secondary data were situated in the background and literature whereas the primary data constituted responses from participants in Ga West Municipality.

\section{Findings}

The key findings of the study are categorized in line with the research questions and key variables investigated.

\subsection{Benefits of Capitation Grant on Basic Schools in Ga West Municipality 4.1.1. Enrolment}

The trend in enrolment in the Municipality from 2001 to 2015 is presented in Figure 9. As shown in Figure 9, before the introduction of the Capitation Grant Scheme in 2005, enrolments in public basic schools in the then Ga West District in 2004, which was created from Ga District was 26,742 but increased to 43,130 in 2007 and further to 54,854 in 2009/10. At the time of introduction, the amount was $\mathrm{GH} \phi 3$ per pupil, but was increased to $\mathrm{GH} \phi 4.5$ in 2009. This probably, could account for the further increase in enrolment in 2009 and 2010. It however decreased to 27,509 in 2011. The discrepancy or low enrolment for the period 2010/11 to 2014/15 could be attributed to the further split of the district in 2008 to current Ga West and Ga South Municipalities. The pre-2010/11 enrolment figures must have included schools which are now in other districts and municipalities before the separation in 2008. Nevertheless, enrolment has steadily increased from 27,509 in 2010/11 to 37,245 in 2014/15. This increase, although low, could be attributed to the Capitation Grant.

\subsubsection{Teaching and Learning}

Teaching and learning materials play important roles in classroom interaction. Table 1 shows the responses of teachers on how the introduction of the Capitation Grant affected the production and use of teaching and learning materials in large classes.

Table-1. Improvement in Teaching and Learning as a result of the grant

\begin{tabular}{l|l|l}
\hline Improved Teaching and Learning & Frequency & Percentage \\
\hline To a large extent & 20 & 26.7 \\
\hline To some extent & 48 & 64.0 \\
\hline Not at all & 7 & 9.3 \\
\hline Total & 75 & 100 \\
\hline Source: Field data, 2016 &
\end{tabular}


According to the respondents, as shown in Table 1, the introduction of the Scheme encouraged the production and use of teaching and learning materials. A combined score of $90.7 \%$ of the respondents said the scheme improved teaching and learning, with only 7 (9.3\%) saying it did not improve teaching and learning. The introduction of the Capitation Grant Scheme was to help public schools have access to teaching and learning materials to enhance education delivery. It was therefore not surprising that majority of the participants saw an improvement in the provision of teaching and learning materials. This finding is congruent with the argument of Bonney (2006) and Drucker (2006) that any intervention that addresses the central pillars of education (teaching and learning) is warranted and should be sustained.

\subsection{Influence of Capitation Grant on Parents to Send Their Children to School}

On the variable, influence of the introduction of Capitation Grant Scheme on parents to send their children to school, $42(94 \%)$ of the respondents said there had been some influence and 3(6\%) said the introduction of the scheme had not got any influence on them (parents) sending their children to school. From the responses of the head teachers and teachers, one can deduce that the grant largely had an influence on parents sending their children or wards to school. The implication is that parents who could not pay the levies that were being charged by the school had the opportunity to send their children to school. Despite the increase in enrolment, some children were still out of school. This could possibly explain why some of the respondents said the introduction of the capitation grant did not have any influence on the parents sending their children to school.

Table-2. Head teachers' and teachers' perceptions on state of accommodation

\begin{tabular}{l|l|l}
\hline State of Accommodation & Frequencies & Percentages \\
\hline Excellent & - & - \\
\hline Very Good & 9 & 10 \\
\hline Good & 18 & 20 \\
\hline Poor & 63 & 70 \\
\hline Total & 90 & 100.0 \\
\hline Source: Field data, 2016 &
\end{tabular}

In Table 2, about $70 \%$ of the respondents indicated that the classroom accommodation situation after the introduction of the grant was poor. About $20 \%$ said the classroom accommodation situation after the introduction of the scheme was good, while only $10 \%$ said the accommodation situation was very good. Analytically, the introduction of the capitation grant rendered the classroom situation poor, apparently owing to the large influx of students in the classroom. This data confirms the literature (see Figure 3) that once the Capitation Grant was introduced and there was no corresponding increase in accommodation, the classroom situation was obviously going to be poor, owing to congestion.

\subsubsection{Availability of Textbooks}

Increase in enrolment had an influence on the availability of textbooks for use by pupils in class (see Table 3 ).

Table-3. Teachers' perception on availability of textbooks in schools

\begin{tabular}{l|l|l}
\hline Percentage of students with textbooks & Frequencies & Percentages \\
\hline $1-20 \%$ & 1 & 1.3 \\
\hline $21-40 \%$ & 5 & 6.7 \\
\hline $41-60 \%$ & 6 & 8.0 \\
\hline $61-80 \%$ & 41 & 54.7 \\
\hline $81-100 \%$ & 22 & 29.3 \\
\hline Total & 75 & 100.0 \\
\hline Source: Field data, 2016 &
\end{tabular}

As shown in Table 3, responses from teachers on available textbooks show that only about $8 \%$ responded that up to $40 \%$ of pupils in their classes had access to textbooks. On the other hand, $54.7 \%$ said between $61 \%$ and $80 \%$ of pupils in their classes had access to textbooks while $29 \%$ responded that between $81 \%$ and $100 \%$ of pupils had textbooks in their classes. The significance of textbooks in schools especially at the basic level cannot be overemphasized- hence, this data reflects a serious challenge to the policy.

The researchers' interactions with head teachers of the study schools revealed that, textbooks were supplied based on the enrolment figures for 2009/10 academic year, after the split of the municipality. Increased enrolment in schools had implicitly made the available textbooks inadequate as $29 \%$ of teachers admitted that between $81 \%$ and $100 \%$ pupils had access to all textbooks. The data lend support to the argument made by the Ghana National Education Campaign Coalition in 2012 that the improvement in the quality of basic education depends on pupiltextbook ratio.

\subsubsection{Pupil-Teacher Ratio}

From the data collected, about $97.6 \%$ of teachers regarding the number of pupils in their class show that some classes had as many as seventy pupils. In the case of some Junior High Schools, $95.3 \%$ of teachers who taught more than one subjects, taught more than two hundred pupils. The study generally found that there had been an increase in the pupil-teacher ratio as a result of the increased enrolment, due to the introduction of the capitation grant scheme. This situation definitely does not offer a better opportunity for pupil-teacher interaction. Teachers apparently found it difficult controlling, supervising and marking exercises. Implicit here then is the belief that teaching and learning was therefore not effective. The data on pupil-teacher ratio confirm documentary evidence in the literature (see 
Figure 9) which show a decline in pupil-teacher ratio especially in the 2005/06 academic year, although the PTR did not go above GES standard of 35:1 (World Bank, 2011).

\subsubsection{Impressions on the Amount per Pupil}

The manner in which people accept or reject a new policy or idea depends on their impressions about that new policy or idea. When asked to give their impressions on the GHф4.5 paid for each pupil per annum, whether it was sufficient or not, the following were the responses from teachers and head teachers. All the 15 head teachers and $95 \%$ of the 75 teachers said the amount was not adequate to support the running of their schools. Only 5\% of the teachers said the amount was adequate. This implies that, head teachers and teachers were of the view that the $\mathrm{GH} \notin 4.50$ per pupil, per annum given to public basic schools was largely inadequate. The inadequacy of the grant has attracted some comments from sections of the Ghanaian society. For example, the Integrated Social Development Centre (ISODEC), after commending the government for implementing child-friendly policies and programmes, for example, the Capitation Grant, also appealed to the government to increase the Grant of GH $₫ 4.5$ per pupil per annum (World Bank, 2011). Also, the Committee of Heads of Basic Schools (CHOBS) commented on this point earlier by describing the GHф4.5 as meagre and appealed to the government to increase it to GHф6.0 (Bonney, 2006).

The impressions of parents were not different from those expressed by the head teachers and teachers on the amount paid per pupil (see Table 4).

Table-4. Attitude of Parents towards the Capitation Grant Scheme

\begin{tabular}{l|l|l}
\hline Attitude & Frequency & Percentage \\
\hline Supportive & 40 & 88.9 \\
\hline Not Supportive & 5 & 11.1 \\
\hline Total & 45 & 100 \\
\hline Source: Field data, 2016
\end{tabular}

As can be seen in Table 4, only 5 out of 45 parents were not supportive of the grant. The researchers' deduction is that, most parents did not want to contribute, (cash or kind) towards the running of the school as a result of the grant government is paying to the schools. It might reasonably be claimed from the data that some parents viewed the introduction of the capitation grant as an avenue for an absolutely free educational intervention in which they (parents) will not have any financial responsibility for their children's education.

Similarly, parents considered the Capitation Grant to relieve them of fees and other expenses they incur. As can be seen in Table 5, the capitation grant brought great relief to parents as $60 \%$ of them said it brought great relief to them through exemption from payment of fees. About 35.6\% said it brought relief in the area of fees and provision of school materials while $4.4 \%$ said it brought relief due to the provision of school materials by the government.

Table-5. Relief of the capitation to parents

\begin{tabular}{l|l|l}
\hline Relief & Frequencies & Percentages \\
\hline Fees & 27 & 60.0 \\
\hline School materials by the government & 16 & 35.6 \\
\hline Fees and material & 2 & 4.4 \\
\hline Total & 45 & 100 \\
\hline Source: Field Data, 2016
\end{tabular}

This means that parents saw the non-payment of fees, provision of textbooks and exercise books by the government as a good motivation in helping them send their children to school. By implication, it means and as seen in the view of UNESCO (2006) such intervention by the government of Ghana should be sustained.

\subsection{Impediments to the Full Implementation of the Grant}

From open-ended responses, the researchers gathered from respondents that the introduction of the capitation grant was being faced with the following problems:

- Head teachers found it very difficult preparing the school performance improvement plans (SPIP) for their school. This was a condition for accessing the capitation grant.

- Teachers who were not heads did not have enough information on the scheme and its management.

- Teachers did not co-operate with their head teachers in the preparation of the school performance improvement plans. They did not make inputs of their needs into the SPIP but would like to have some money spent on their needs when the money had been released.

- Head teachers found it very difficult preparing their cashbooks, because they apparently had little or no knowledge in accounting, and thus found difficulties in accessing the grant.

- Head teachers complained about the number of documents to be completed for a single activity performed which made their work cumbersome.

The conclusion that can be drawn from the above account is that more determined effort should be applied to train and orientate school authorities on responsibilities that come along with accessing the grant. Dzamboe (2005) acknowledges that every intervention or policy has its inherent challenges, hence, it is incumbent on the GES to organize workshops in coping with these challenges.

\subsection{Ways by which Capitation Grant can be used to Improve Education Delivery}

When asked to suggest ways of improving the scheme, the following suggestions from open-ended questions were given by the respondents:

- Early release of the grant to schools.

- District quota deduction should not to be taken once but spread to cover the whole year. 
- Increase of the amount of $\mathrm{GH} \phi 4.50$ per pupil per annum to $\mathrm{GH} \phi 10.00$

- Provision of more educational facilities like additional classrooms, furniture and textbooks, to cater for the increasing numbers.

- More teachers should be trained.

- More educational programmes on the scheme should be organized to sensitise parents to play their roles to augment the effort of the government.

- Parent -Teacher Associations (PTAs) should continue to support schools in which their wards are enrolled, by paying dues or PTA contributions.

It is clear from the suggestions that, timeous disbursement of the Capitation Grant, increase in the amount per child relative to the grant, improved infrastructure, more manpower (especially teachers) and continuing education regarding the implementation of the grant were key for improving education delivery under the grant. But much to be emphasized is the expected education of various PTAs as key stakeholders in implementing the Capitation Grant.

\section{Conclusion and Implications}

Parents saw the introduction of the scheme as a great relief to them. The data indicate increased enrolment in all the schools sampled. This meant children of school-going age who were not in school took advantage of the introduction of the scheme to go to school. However, a side effect of this was congestion in schools, inadequate accommodation and furniture, high pupil-teacher ratio, shortages in teaching and learning materials, and textbooks. It therefore, behoves government to institute appropriate measures to address these problems.

The results of the research showed an increase in enrolment since the introduction of the capitation grant scheme. This was apparently due to the fact that, parents who hitherto could not afford the levies that were being charged in schools could now send their children to school. Findings of the study imply that the scheme will help more children who are not in school to be enrolled. It must be noted that if the law on compulsory education is not enforced, parents will not feel compelled to send their children to school. When children of school-going age do no go to school, the country cannot achieve the aim of having all children of school going age in school. The introduction of the Capitation Grant Scheme, if sustained, could be a way of achieving the objectives of the Education for All (EFA) and the Sustainable Development Goals. Stakeholders in education should therefore, ensure the sustainability of the scheme.

\subsection{Recommendations}

- To minimize the delays encountered in the payment of the Capitation Grant to the schools, as revealed in the findings the Director in charge of basic education should work hand in hand with the District Directors and Ministry of Finance to compile the account numbers and banks of all the basic schools to enable payment of the grant directly into the accounts of the schools.

- Based on the inadequacy of the funds as shown in the results, the Ministry of Education in collaboration with the Ministry of Finance should make budgetary allocations with the help of Non-Government Organisations (NGOs) like the United States Agency for International Development (USAID) and World Vision International for the provision of classroom accommodation throughout the country to help solve the problem of inadequate classrooms as a result of the introduction of the Capitation Grant Scheme.

- The results revealed inadequacy of furniture in the schools; the District Education Oversight Committee (DEOC) and the District Assemblies should therefore seek the help of Non-Governmental Organizations in their districts to assist in providing furniture for the schools to help solve the problem of inadequate furniture.

- The Ministries of Education and Finance should make sure the programme is sustained by providing the funding needed for the programme each year. This can be done by allocating about ten per cent of the Ghana Education Trust Fund (GETFUND) money to the payment of the capitation grant for basic schools each year.

- District Directors of Education, Circuit Supervisors and School Management Committee members should organize forums to educate parents to make them aware of their role on the education of their children.

- District Assemblies should promulgate Bye-Laws to enable parents who refuse to send their children to school sanctioned.

- The supply and logistics division of the Ghana Education Service, should acquire more trucks that will enable them ensure timely delivery of textbooks and exercise books from the headquarters to the basic schools.

- The Teacher Education Division of the Ghana Education Service should make provision for more workshops to be organized for all heads of basic schools to enable them better understand the management process of the grant.

- Assistant Directors in charge of Supervision should ensure that workshops are organized for all teachers who are not heads, to enlighten them on the preparations of School Performance Improvement Plans and records keeping with reference to the Capitation Grant Scheme.

\section{References}

Adedze, V., 2005. Capitation grant increases enrolment in schools. Daily Graphic Friday December 23, No. 149619: 11

Agyeman, D.L., 2013. Sociology of education for African students. Accra North: Ghana Black Mask Ltd.

Akyeampong, K., J. Djangmah, A. Seidu, A. Oduro and F. Hunt, 2007. Access to basic education in Ghana: The evidence and the issues. Country Analytic Report. CREATE.

Antwi, M.K., 1992. Education, society and development in Ghana. Accra: Ghana Unimax Publishing Limited.

Atagra, C., 2005. Capitation raise school enrolment by 9.3\%. Ghanaian Times Wednesday December 21, No. 14712: 21. 
Bonney, E., 2006. Capitation grant, free ride and school feeding; the catalyst for high enrolment. Daily Graphic Friday December 23, No. 149619: 11

Denison, E.F., 2007. The sources of economic growth in the United State and the alternatives before us. New York: Committee for Economic Development.

Drucker, P.F., 2006. Landmarks of tomorrow. New York: Harper and Bros.

Dzamboe, T., 2005. Capitation grant does it; enrolment doubles in North Tongu District. Daily Graphic Saturday October 22, No. $149566: 27$.

Ghana Statistical Service (GSS), 2014. District analytical report: Ga West Municipality, 2010 population and housing census. Accra: GSS.

Mcwilliam, H.O.A. and M.A. Kwamena-Poh, 1975. The development of education in Ghana. New Edn., London: Longman.

Ministry of Education (MOE), 2001. Education management information system (EMIS) (2001 - 2015). Report on Basic Statistics and Planning Parameters for Basic Education in Ghana. Accra: Ministry of Education.

Ministry of Education Science and Sports, 2005. Linking ESP and the White Paper Reform, November 2005. Accra: MOESS.

UNESCO, 2006. EFA global monitoring report 2007: Strong foundations early childhood care and education. Paris: UNESCO Publishing.

UNICEF, 2006. Abolition of school fees, issue Briefing Note No. 9. Accra: UNICEF

UNICEF, 2015. Implementation of the Ghana shared growth and development agenda (GSGDA), 2010-2013. 2014 citizens' assessment report on the capitation grant scheme "is the capitation grant achieving the objective of eliminating fees and charges at the basic school level?. Accra: UNICEF

UNICEF, 2016. The state of the world's children 2016: A fair chance for every child. New York, USA: UNICEF.

World Bank, 2011. Education in Ghana: Improving equity, efficiency and accountability of education service delivery. Report No. 59755-GH, Republic of Ghana. AFTED Africa Region.

\section{Bibliography}

Ministry of Education Science \& Sports, 2006. Report on the education sector annual review (ESAR) June 2006. Accra. Retrieved from http://planipolis.iiep.unesco.org/sites/planipolis/files/ressources/ghana_esar_2006_report_final.pdf.

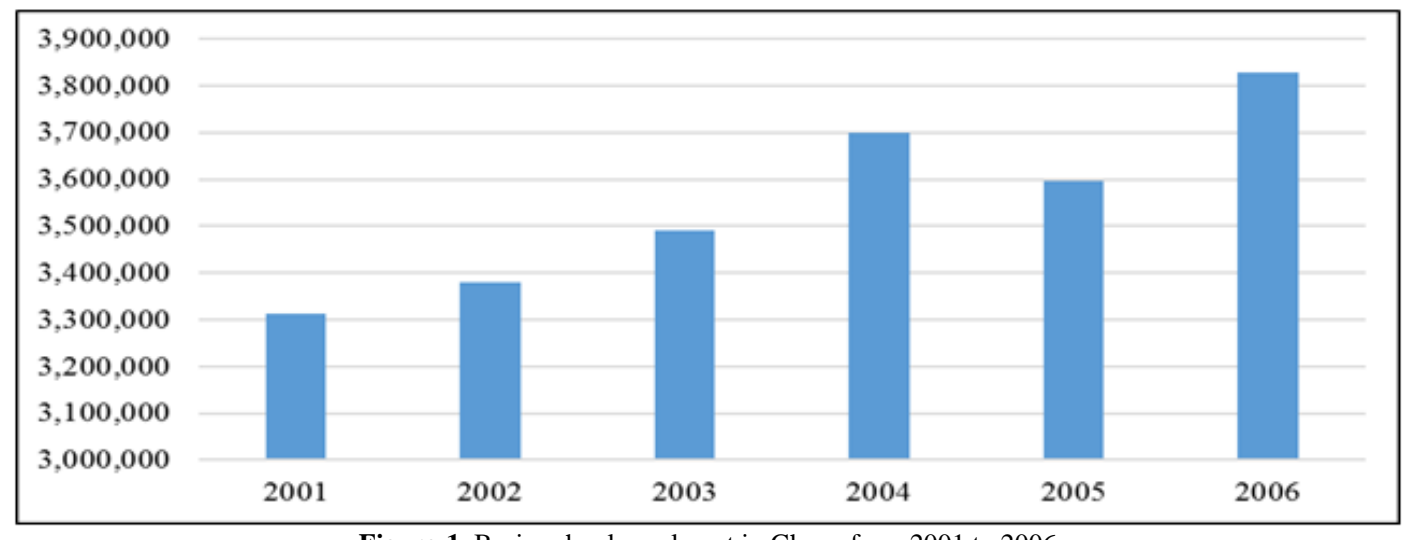

Source: Computed from MOE/EMIS (2001 - 2007)

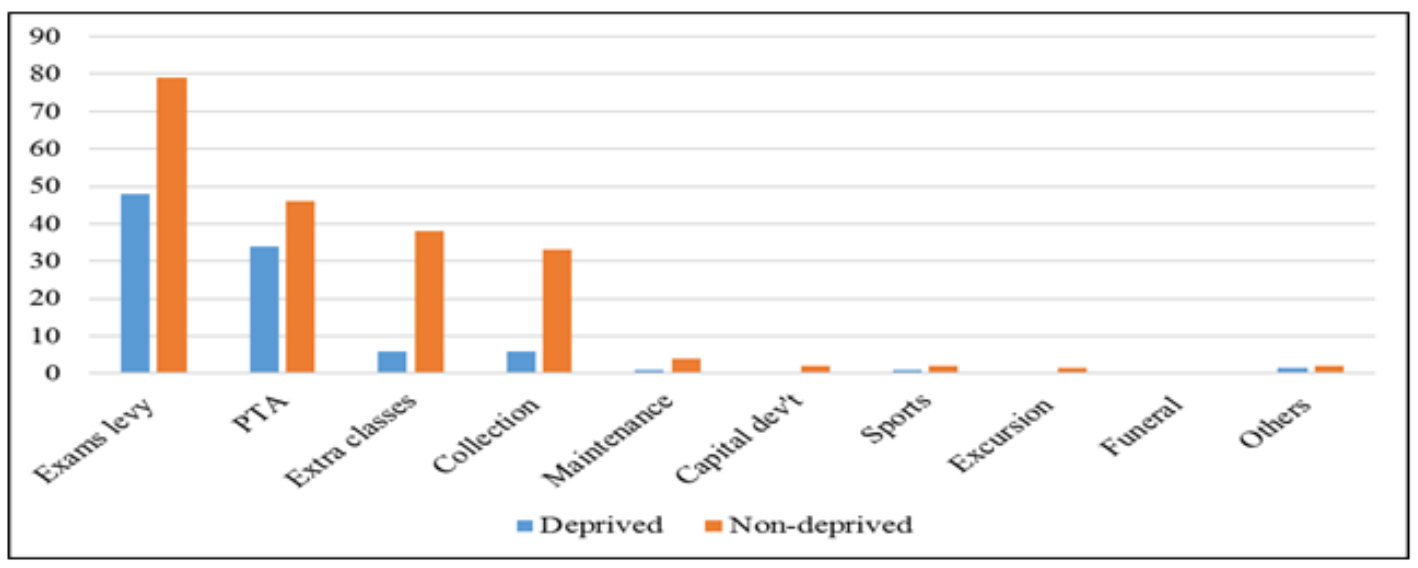

Source: UNICEF (2015)

Figure-2. Fees capitation grant seeks to alleviate

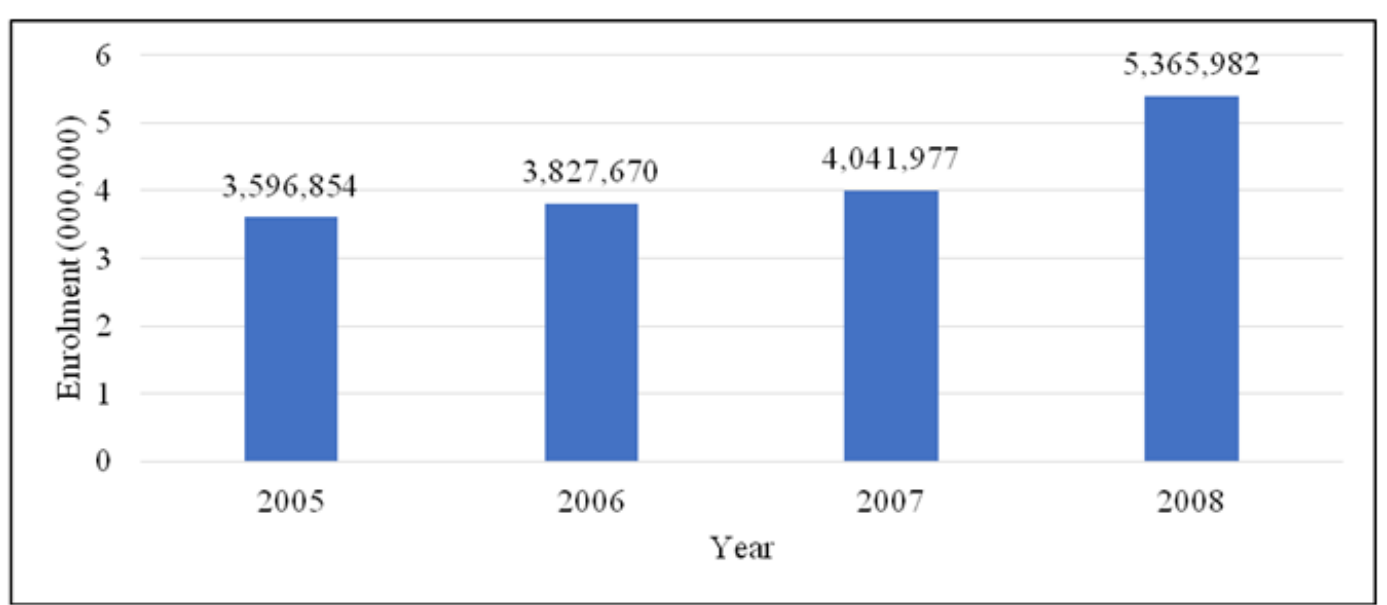

Figure-3. Enrolment in Basic schools from 2005 to 2008

Source: Computed from MOE/EMIS (2005 - 2009) 


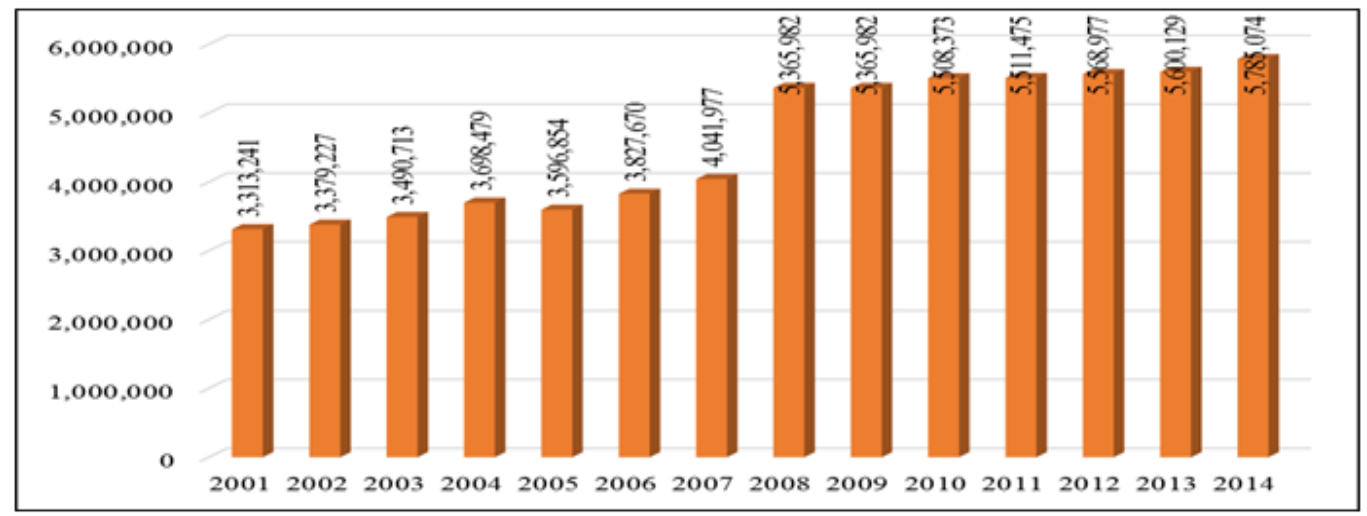

Figure-4. Gross Enrolment Rates in Basic Schools in Ghana

Source: Computed from MOE/EMIS Data $(2001-2015)$

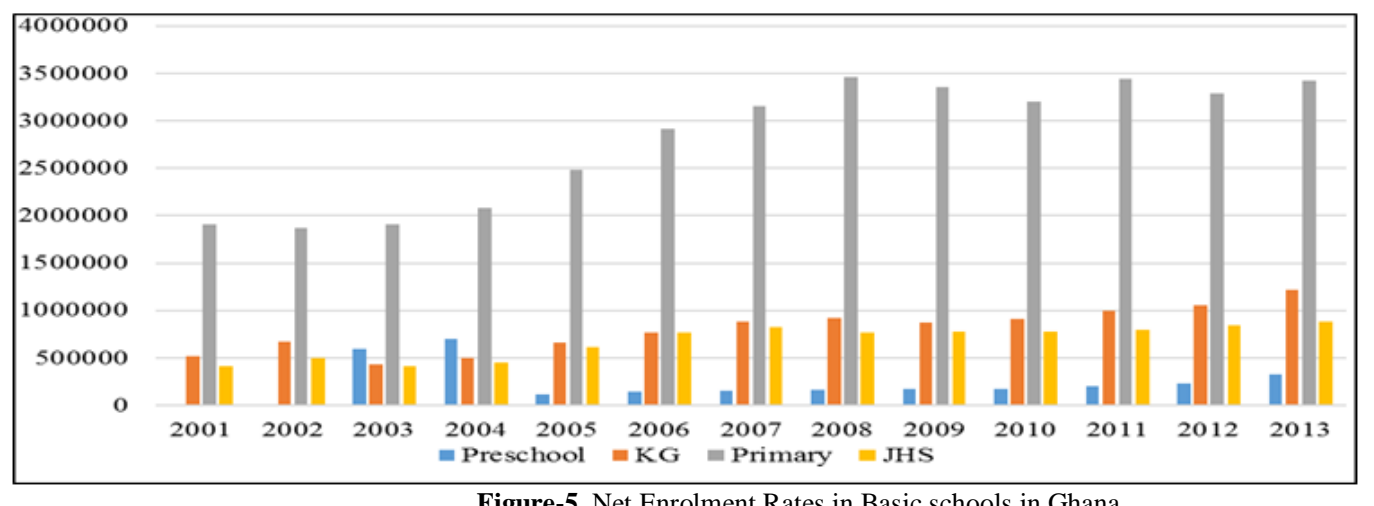

Source: Computed from MOE/EMIS, 2014

Figure-5. Net Enrolment Rates in Basic schools in Ghana

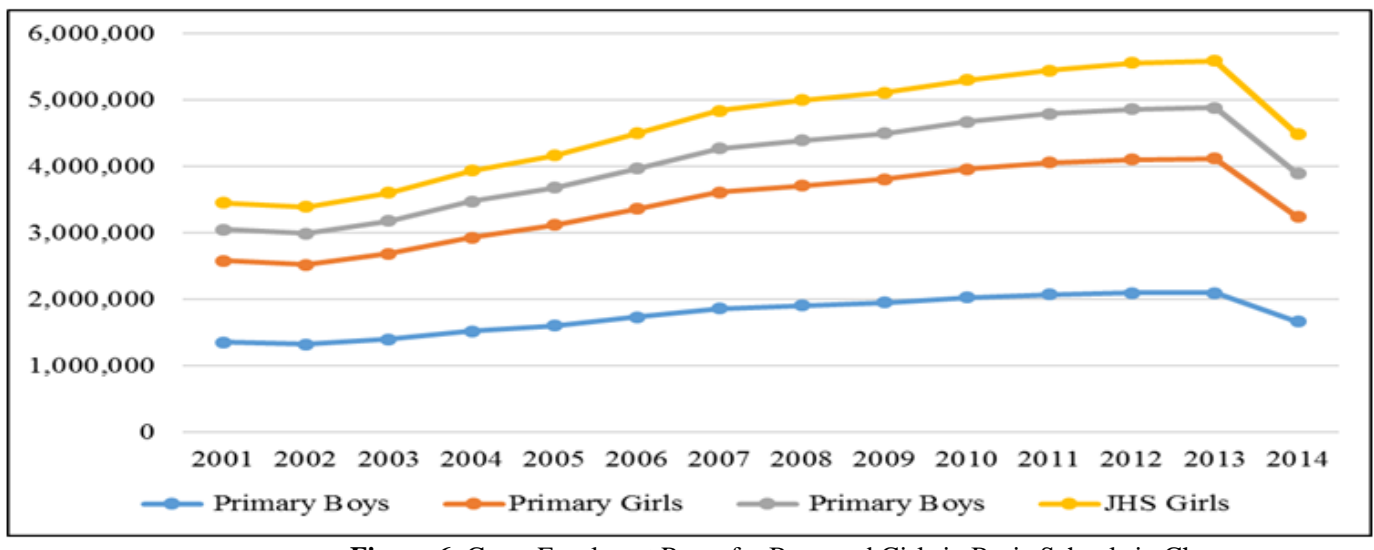

Figure-6. G
Source: Computed from MOE/EMIS 2015

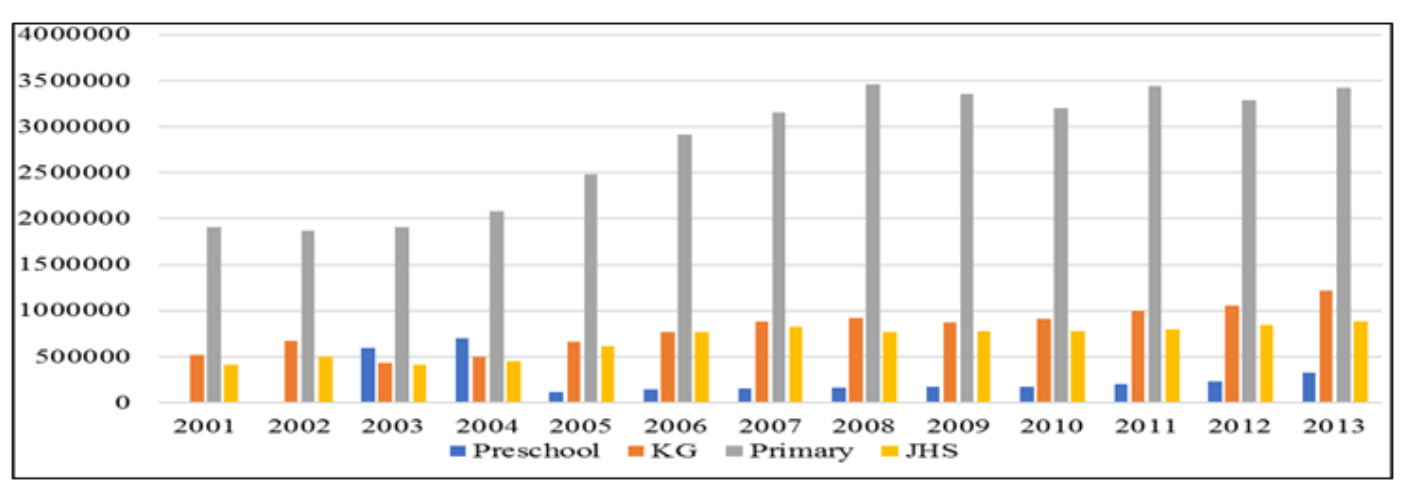

Figure-7. Net Enrolment Rates for Boys and Girls in Basic Schools in Ghana

Source: Computed from MOE/EMIS (2001 - 2014)

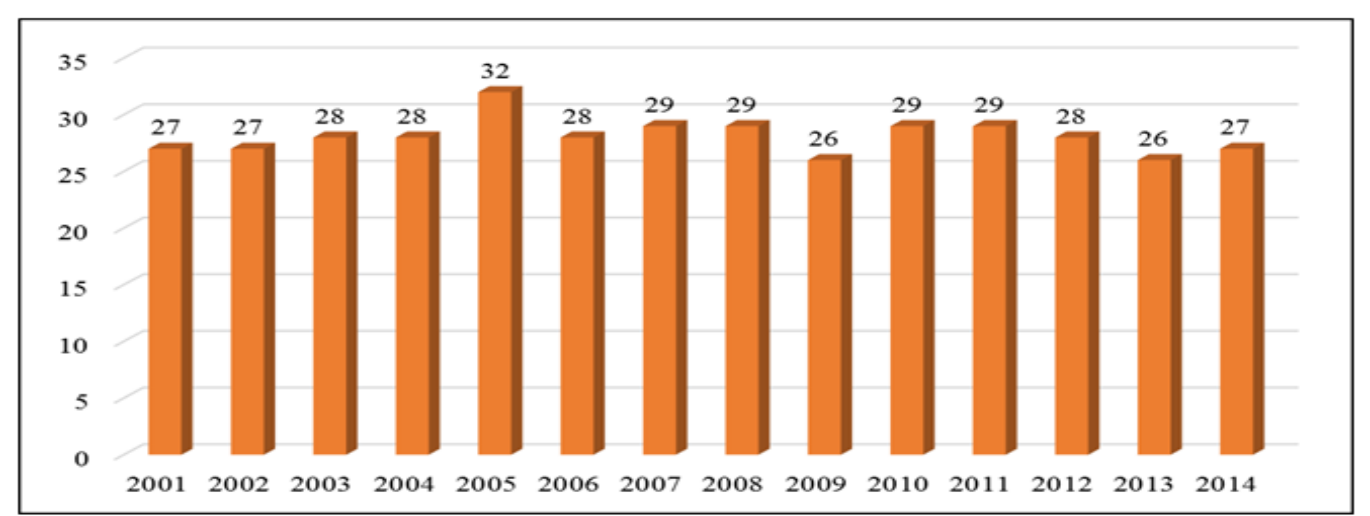

Figure-8. Pupil Teacher Ratio in basic public schools in Ghana

Figure-8. Pupil Teach
Source: Computed from MOE/EMIS, 2001 - 2015 
Asian Journal of Education and Training, 2017, 3(1): 53-63

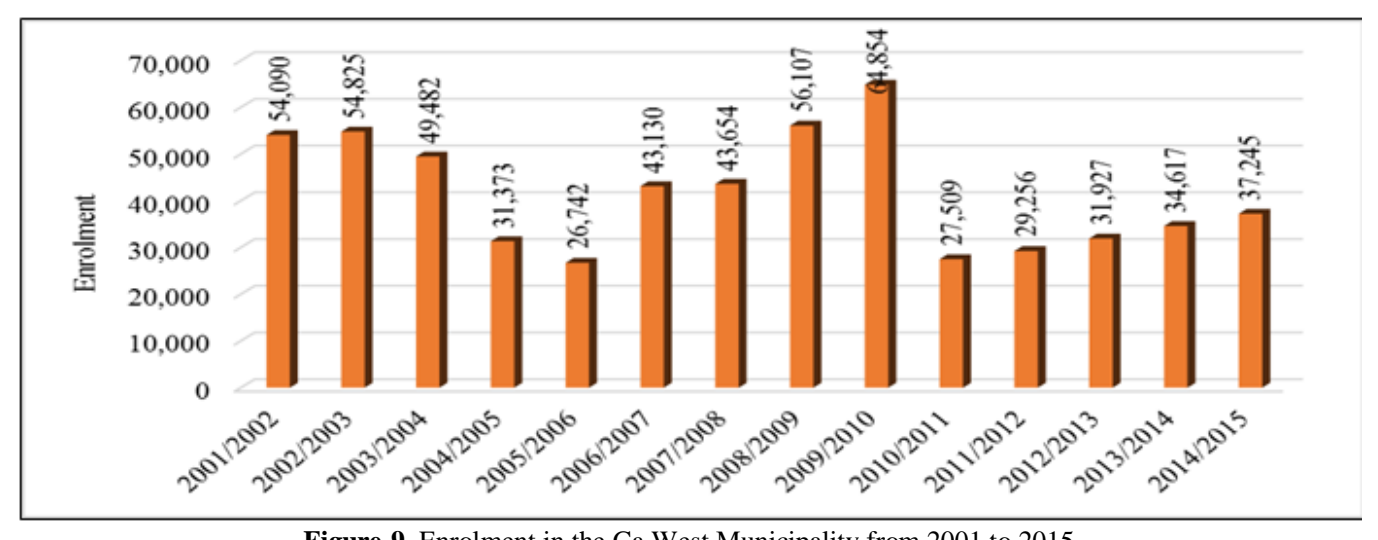

Figure-9. Enrolment in the Ga West Municipality from 2001 to 2015

Source: Computed from MOE/EMIS, 2001 - 2015 